\title{
The Comparative Efficiency of Organic, Mineral and Organo- Mineral Fertilizers for the Winter Wheat Grain Yield in the Forest- Steppe of the Volga Region
}

\author{
Alevtina Kulikova, Evgeniy Yashin, Alexander Karpov and Elena Volkova* \\ Ulyanovsk State Agrarian University named after P.A. Stolypin, Ulyanovsk, Russia
}

\begin{abstract}
The study deals with organic, mineral and organo-mineral systems of winter wheat fertilization in the conditions of the Volga forest-steppe. According to the organic fertilization system, straw of the predecessor, green manure and Biocomposite-correct were introduced into the soil (typical medium-thick medium loamy chernozem) for green manure mass (vetch-oat mixture). The organo-mineral system included two options: straw applied together with nitrogen in a dose of $10 \mathrm{~kg}$ per 1 ton of straw and zeolite enriched with amino acids. The mineral fertilizers were nitrogene phosphorus with the NPK content of $16 \mathrm{~kg}$ ai/ha, carbamide and potassium chloride. In addition, highly siliceous rock zeolite was applied as a fertilizer. It was found that the use of organic and organomineral fertilizers improves the nutrient regime of the soil; in terms of the content of nitrogen, phosphorus and potassium in the arable layer, these options were not inferior to the option with the use of mineral fertilizers. When introducing zeolite enriched with amino acids, the yield of winter wheat exceeded the option with the use of mineral fertilizers by $0.59 \mathrm{t} / \mathrm{ha}$. The use of organic and organo-mineral fertilizers contributes to the production of environmentally friendly products.
\end{abstract}

\section{Introduction}

In modern conditions of agricultural production, one of the strategic directions of sustainable development of the agro-industrial complex is the elimination of antagonistic contradictions between human activities and agroecosystems, ensuring food, environmental and economic security. The development of technologies for the cultivation of crops that meet these requirements is one of the most important problems in agriculture.

It is possible to harmonize human economic activities with the laws of nature, which involves the maximum use of biogenic resources of the agroecosystems as fertilizers (straw and other plant residues, green manure, biological preparations, etc.). However, only biological means can solve the problem of plant nutrition; in some cases, it is not always possible to cope with the problems arising in the cultivation of crops. In addition, the problem of reproduction and preservation of soil fertility remains unresolved. Organic fertilizers listed above, including straw of grain crops, are crucial.

Numerous studies have established that one ton of straw is equivalent to three tons of manure; its systematic use can preserve the humus and improve almost all agronomically important soil properties (physical, biological, agrochemical). However, due to its chemical composition (a wide ratio of carbon to casot), it is difficult to decompose; its inhibitory effect on plants is a result of the release of toxic substances during the decomposition. In the light of organic agriculture, the search for ways to accelerate the decomposition of straw is extremely important. It is possible to use biological preparations that activate soil microorganisms. It is necessary to develop a set of techniques to produce environmentally safe high-quality products and preserve soil fertility. The research purpose was to study the comparative effectiveness of organic, mineral and organo-mineral fertilizers in the cultivation of winter wheat.

Winter wheat in the Volga region is one of the highest-yielding, demanded grain crops. It is well adapted to the conditions of the region and is capable of forming the yield of up to $8-10 \mathrm{t} / \mathrm{ha}$ in favorable years [1]. However, modern varieties of winter wheat are capable of realizing their potential only against the background of high mineral nutrition and neutral reactions of the soil environment.

As a rule, the higher yield is possible with the use of high doses of mineral fertilizers. However, the latter are fraught with significant risks of obtaining environmentally unsafe products; the environmental pollution and is not always economically justified. The above was taken into account when drawing up a scheme of field experiments.

\footnotetext{
Corresponding author: volkova-ivinaelena@yandex.ru
} 


\section{Materials and methods}

The study of the comparative effectiveness of organic, mineral and organo-mineral fertilizers in the technology of cultivation of winter wheat was carried out on the experimental field of Ulyanovsk State Agrarian University named after P.A. Stolypin.

The field experiment scheme included seven options:

1. Control (without fertilizers)

2. Straw of the predecessor for green manure + green manure

3. Straw $+10 \mathrm{~kg}$ nitrogen per 1 ton of straw $(10 \mathrm{~kg} \mathrm{~N} / \mathrm{t})$

4. Straw + biological product + green manure

5. N64P32K54 (NPK)

6. Zeolite, $500 \mathrm{~kg} / \mathrm{ha}$

7. Zeolite enriched with amino acids, $500 \mathrm{~kg} / \mathrm{ha}$.

Thus, winter wheat was cultivated against the background of natural fertility (control, option 1), organic (options 2 and 4), mineral (options 5 and 6) and organo-mineral (options 3 and 7) fertilizers.

The experiment was repeated four times, the area of the plots was $20 \mathrm{~m}^{2}(2 \times 10)$, their placement was randomized. Winter wheat (Saratovskaya 17) was cultivated on green manure fallow. Saratovskaya 17 has an increased winter hardiness, drought resistance, and lodging resistance. The potential yield is higher than 6 $\mathrm{t} / \mathrm{ha}$. Straw of the predecessor (barley) was covered with green manure.

The plant mass (straw, stubble and root residues) was treated with Biocomposite-Correct produced by JSC Shchelkovo Agrokhim. The drug is a consortium of valuable strains of several beneficial bacteria with phytoprotective, growth-stimulating, destructive, nitrogen-fixing and phosphate-mobilizing properties. As a mineral fertilizer, we used nitrophoska containing 16 $\%$ nitrogen, phosphorus and potassium, urea and potassium chloride. The dose of fertilizers was calculated to receive 4.5 tons of grain from 1 hectare.

Two options with zeolite from the Yushansk deposit as fertilizers and a zeolite organo-mineral fertilizer enriched with amino acids were introduced into the scheme. Numerous studies have established the effectiveness of natural siliceous rocks in improving the soil properties and producing environmentally friendly products [2-6]. It is also promising to produce highly effective organo-mineral fertilizers that meet the requirements for the nutritional regime.

Together with BioResource (Ulyanovsk), the authors developed a composition and technology for the production of zeolite fertilizers based enriched with amino acids of animal origin, which include 17 amino acids: aspartic acid, glutamic acid, serine, histidine, glycine, threonine, arginine, alanine, tyrosine, cystine, valine, methionine, phenylalanine, isoleucine, leucine, lysine, and proline.

The soil of the experimental field was typical mediumthick medium loamy chernozem with the following agrochemical characteristics: humus content in the arable layer was $4.7 \%$, available phosphorus was $155 \mathrm{mg} / \mathrm{kg}$ soil, potassium was $106 \mathrm{mg} / \mathrm{kg}$, pHKCl was 6.7 units.

\section{Results and discussion}

The yield of winter wheat, depending on the fertilizers, is presented in Table 1.

Table 1. The influence of fertilizers on the yield of winter wheat, 2020

\begin{tabular}{|c|c|c|c|}
\hline Options & Productivit & \multicolumn{2}{|c|}{ Deviation, $\mathbf{\pm}$} \\
\cline { 3 - 4 } & $\mathbf{y}, \mathbf{t} / \mathbf{h a}$ & $\mathbf{T} / \mathbf{r a}$ & $\mathbf{\%}$ \\
\hline Control & 5.83 & - & - \\
\hline $\begin{array}{c}\text { Straw + green } \\
\text { manure }\end{array}$ & 6.33 & +0.50 & 9 \\
\hline Straw + 10 kg N/t & 6.94 & +1.11 & 19 \\
\hline $\begin{array}{c}\text { Straw + biological } \\
\text { product + green } \\
\text { anure }\end{array}$ & 6.82 & +0.99 & 17 \\
\hline NPK & 7.25 & +1.42 & 24 \\
\hline Zeolite, 500 kg/ha & 6.59 & +0.76 & 13 \\
\hline $\begin{array}{c}\text { Zeolite enriched with } \\
\text { amino acids, 500 } \\
\mathrm{kg} / \mathrm{ha}\end{array}$ & 7.84 & +2.01 & 34 \\
\hline LSD05 & 0.31 & & \\
\hline
\end{tabular}

As follows from the table, the climatic conditions of the Middle Volga region make it possible to have a high yield of winter wheat, which amounted to almost $6 \mathrm{t} / \mathrm{ha}$. This was facilitated by a good overwintering of crops, optimal moisture supply, a favorable temperature regime, and provision of soil with phosphorus and potassium compounds. However, due to the low humus content, the supply of mineral forms of nitrogen is low, which can decrease the yield.

The application of a vetch-oat mixture which is a nitrogen-potassium fertilizer can improve the nitrogen nutrition of plants and optimize the nutrient regime of the soil. According to A.E. Yashin [7], straw of the predecessor and green manure return $28.5 \mathrm{~kg} / \mathrm{ha}$ of nitrogen to the soil, when this mass is treated with Baikal EM -1 due to an increase in the yield of green manure by $39.8 \mathrm{~kg} / \mathrm{ha}$, while in the control option it is $-14.4 \mathrm{~kg} / \mathrm{ha}$. The above is confirmed by the data in Table 2 .

The data indicate that the treatment of the plant mass of straw with a biological product contributed to a slight increase (by $0.4 \mathrm{mg} / \mathrm{kg}$ ) in the content of mineral forms of nitrogen in the topsoil. According to the results of previous studies, for the transformation of straw with a narrow $\mathrm{C}$ : $\mathrm{N}$ ratio, it is necessary to use nitrogen when using straw as a fertilizer in the amount of at least 10-20 kg per 1 ton of straw [8]. In this case, the use of additional nitrogen at the rate of $10 \mathrm{~kg}$ per 1 ton of straw increased the content of mineral nitrogen in the arable layer by $1 \mathrm{mg} / \mathrm{kg}$, or $10 \%$. With the combined use of straw, biological products and green manure, the amount of mineral forms of nitrogen was $11.8 \mathrm{mg} / \mathrm{kg}$, which is $15 \%$ higher than in the control option.

However, higher values of the content of available nitrogen were observed in the options with zeolite introduced into the soil both in pure form and enriched with amino acids, which amounted to 12.6 and $13.9 \mathrm{mg} / \mathrm{kg}$, respectively (21\% and $34 \%$ higher than in the control option). The latter is due to the significant cellulose-degrading activity of the soil. At the same time, 
in the option with a dose of $500 \mathrm{~kg} / \mathrm{ha}$ of zeolite, it was $36.8 \%$; in the option with the use of zeolite enriched with amino acids in the same dose, it was $46.2 \%$, while in the control option, it was $28.2 \%$. The latter ensured a significant release of nitrogen in the mineral form and increased the grain yield of winter wheat. The correlation analysis showed a dependence of the yield of winter wheat on the content of mineral nitrogen in the arable layer (Fig. 1).

Table 2. The content of available nutrients under crops of winter wheat, $\mathrm{mg} / \mathrm{kg}$ of soil (average for the growing season)

\begin{tabular}{|c|c|c|c|c|c|c|}
\hline \multirow[t]{2}{*}{ Options } & \multicolumn{2}{|c|}{$\left(\mathrm{N}-\mathrm{NO}_{3}+\mathrm{N}-\mathrm{NH}_{4}\right)$} & \multicolumn{2}{|c|}{$\mathrm{P}_{2} \mathrm{O}_{5}$} & \multicolumn{2}{|c|}{$\mathrm{K}_{2} \mathrm{O}$} \\
\hline & Content & deviation & content & deviation & content & deviation \\
\hline Control & 10.4 & - & 149 & - & 153 & - \\
\hline Straw + green manure & 10.8 & +0.4 & 153 & +4 & 163 & +10 \\
\hline Straw + $10 \mathrm{~kg} \mathrm{~N} / \mathrm{t}$ & 11.4 & +1.0 & 154 & +5 & 164 & +14 \\
\hline $\begin{array}{c}\text { Straw + biological } \\
\text { product + green anure }\end{array}$ & 11.8 & +1.4 & 156 & +7 & 165 & +12 \\
\hline NPK & 12.4 & +2.0 & 159 & +9 & 169 & +16 \\
\hline Zeolite, $500 \mathrm{~kg} / \mathrm{ha}$ & 12.6 & +2.2 & 158 & +9 & 164 & +11 \\
\hline $\begin{array}{l}\text { Zeolite enriched with } \\
\text { amino acids, } 500 \mathrm{~kg} / \mathrm{ha}\end{array}$ & 13.9 & +3.5 & 161 & +12 & 165 & +12 \\
\hline $\mathrm{LSD}_{05}$ & 0.3 & & 3 & & 4 & \\
\hline
\end{tabular}

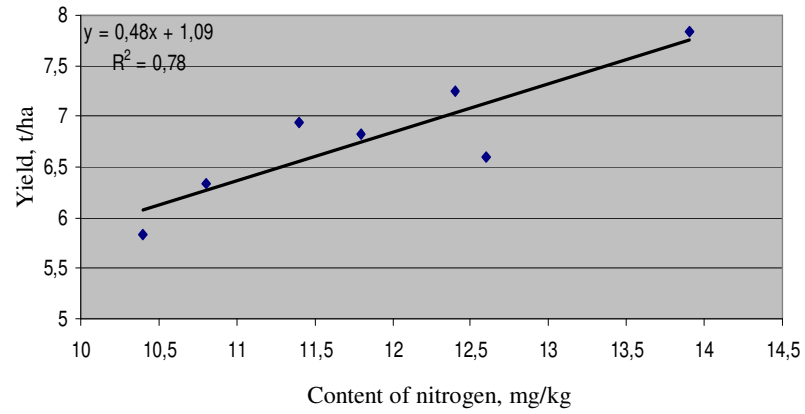

Fig. 1. Dependence of the yield of winter wheat grain on the content of mineral nitrogen in the topsoil

The combined use of straw, green manure and biological products as an organic fertilizer also improved the phosphorus and potassium nutrition of plants. The vetch-oat mixture as a green manure is a nitrogenpotassium fertilizer, since the potassium content in this mixture is more than 2 times higher than the amount of phosphorus. In the scientific literature there are data showing that when green manure is used in crop rotations, $170-400 \mathrm{~kg} / \mathrm{ha}$ of nitrogen, $40-90 \mathrm{~kg} / \mathrm{ha}$ of phosphorus, and $110-310 \mathrm{~kg} / \mathrm{ha}$ of potassium enter the soil $[9,10]$.

Organo-mineral fertilization of winter wheat was also accompanied by a significant increase in the content of available forms of phosphorus and potassium in the topsoil, comparable to the combined use of straw, biological products and green manure. Numerous studies have shown that silicon compounds (in this case, amorphous silicon present in zeolite) contribute to the conversion of unavailable phosphates into the available ones which can reduce the consumption of phosphorus fertilizers by $30-50 \%[11,12]$.

One of the main strategic objectives of organic farming is to produce high-quality and safe products. The data presented in Table 3 confirm that the use of organic and organo-mineral fertilizers improves the quality of winter wheat grain.

Protein and gluten are the main indicators of the quality of wheat grain. In 2020, the protein content was not high and amounted to $9.74 \%$ in the control option, which is a low value. However, when using organic fertilizers, it increased by $0.58 \%$; in the option with the use of zeolite enriched with amino acids it increased by $2.58 \%$. The latter is due to a significant improvement in the nitrogen nutrition of plants and in the general nutritional regime.

Table 3. Indicators of winter wheat grain quality depending on the application of fertilizers

\begin{tabular}{|c|c|c|c|c|c|c|}
\hline \multirow[t]{2}{*}{ Options } & \multicolumn{5}{|c|}{ Content, \% } & \multirow{2}{*}{$\begin{array}{l}\text { IDK, } \\
\text { units }\end{array}$} \\
\hline & $\mathbf{N}$ & $\mathrm{P}_{2} \mathrm{O}_{5}$ & $\mathrm{~K}_{2} \mathrm{O}$ & protein & gluten & \\
\hline Control & 1,71 & 0,74 & 0,55 & 9,74 & 24,1 & 90 \\
\hline $\begin{array}{c}\text { Straw + } \\
\text { green } \\
\text { manure }\end{array}$ & 1,72 & 0,74 & 0,56 & 9,80 & 24,5 & 87 \\
\hline $\begin{array}{c}\text { Straw + } \\
10 \mathrm{~kg} \mathrm{~N} / \mathrm{t}\end{array}$ & 1,77 & 0,78 & 0,58 & 10,09 & 25,3 & 86 \\
\hline $\begin{array}{c}\text { Straw + } \\
\text { biological } \\
\text { product }+ \\
\text { green } \\
\text { manure }\end{array}$ & 1,81 & 0,81 & 0,58 & 10,32 & 25,5 & 82 \\
\hline NPK & 1,77 & 0,78 & 0,58 & 10,09 & 24,8 & 85 \\
\hline $\begin{array}{c}\text { Zeolite, } 500 \\
\mathrm{~kg} / \mathrm{ha}\end{array}$ & 1,91 & 0,78 & 0,62 & 10,89 & 25,5 & 80 \\
\hline $\begin{array}{c}\text { Zeolite } \\
\text { enriched } \\
\text { with amino } \\
\text { acids, } 500 \\
\mathrm{~kg} / \mathrm{ha}\end{array}$ & 2,15 & 0,84 & 0,66 & 12,26 & 26,8 & 75 \\
\hline
\end{tabular}

In the option with zeolite enriched with amino acids, the best quality gluten was observed; its content exceeded the one in the control option by $2.7 \%$.

The use of straw, biological products and green manure is environmentally safe, and there is no danger of contamination of products with toxicants, in particular, with heavy metals (HM).

When they were introduced into the soil, no noticeable changes were observed in the intake of heavy metals into the grain. However, the introduction of zeolite and zeolite fertilizers was accompanied by a very significant decrease in the HM content. The content of the most dangerous elements in grain decreased: lead - by $10 \%$, cadmium by $33-42 \%$ and nickel - by $20-24 \%$. The latter is due to 
the ability of monosilicic acid to form sparingly soluble compounds with heavy metals $[11,13]$.

The use of both organic and, especially, organomineral fertilizers contributes to the production of environmentally friendly products. The use of mineral fertilizers was accompanied by a pronounced trend to increase the supply of heavy metals to products, especially cadmium (by $23 \%$ ) and nickel (by $14 \%$ ).

Table 4. Content of heavy metals in the winter wheat grain, $\mathrm{mg} / \mathrm{kg}$

\begin{tabular}{|c|c|c|c|c|c|}
\hline Options & $\mathbf{Z n}$ & $\mathbf{C u}$ & $\mathbf{P b}$ & $\mathbf{C d}$ & $\mathbf{N i}$ \\
\hline Control & 11,2 & 3,9 & 0,10 & 0,012 & 0,51 \\
\hline Straw + green manure & 11,2 & 3,9 & 0,09 & 0,011 & 0,52 \\
\hline Straw + 10 kg N/t & 11,9 & 3,8 & 0,10 & 0,011 & 0,51 \\
\hline $\begin{array}{c}\text { Straw + biological product + } \\
\text { green manure }\end{array}$ & 11,3 & 3,7 & 0,08 & 0,009 & 0,43 \\
\hline NPK & 10,3 & 3,7 & 0,10 & 0,016 & 0,61 \\
\hline Zeolite, 500 kg/ha & 9,6 & 3,6 & 0,09 & 0,007 & 0,41 \\
\hline $\begin{array}{c}\text { Zeolite enriched with amino } \\
\text { acids, 500 kg/ha }\end{array}$ & 9,7 & 3,6 & 0,09 & 0,008 & 0,39 \\
\hline Control & & & & & \\
\hline Straw + green manure & & & & & \\
\hline
\end{tabular}

One of the main indicators characterizing the sustainability and performance of enterprises producing agricultural products is the economic efficiency of technologies used in the cultivation of agricultural crops using fertilizers due to the constant rise in the their cost. Despite a significant increase in the yield, the production process can be unprofitable. Below are the indicators of economic assessment of winter wheat grain production using different fertilization systems (Fig. 2).

As follows from the above calculations, the cultivation of winter wheat on the chernozems of the Volga forest-steppe with a sufficiently high fertility is highly profitable: its level in the control option exceeds $200 \%$. Undoubtedly, the latter is due to the high crop yield in the given soil and climatic conditions. The highest income was gained when applying straw and nitrogen in a dose of $10 \mathrm{~kg} / \mathrm{t}$ (50.3 thousand rubles/ha), and zeolite enriched with amino acids in a dose of $500 \mathrm{~kg} / \mathrm{ha}$ (54, 6 thousand rubles/ha. Despite the higher profitability, the application of mineral fertilizers is less profitable than the control option.

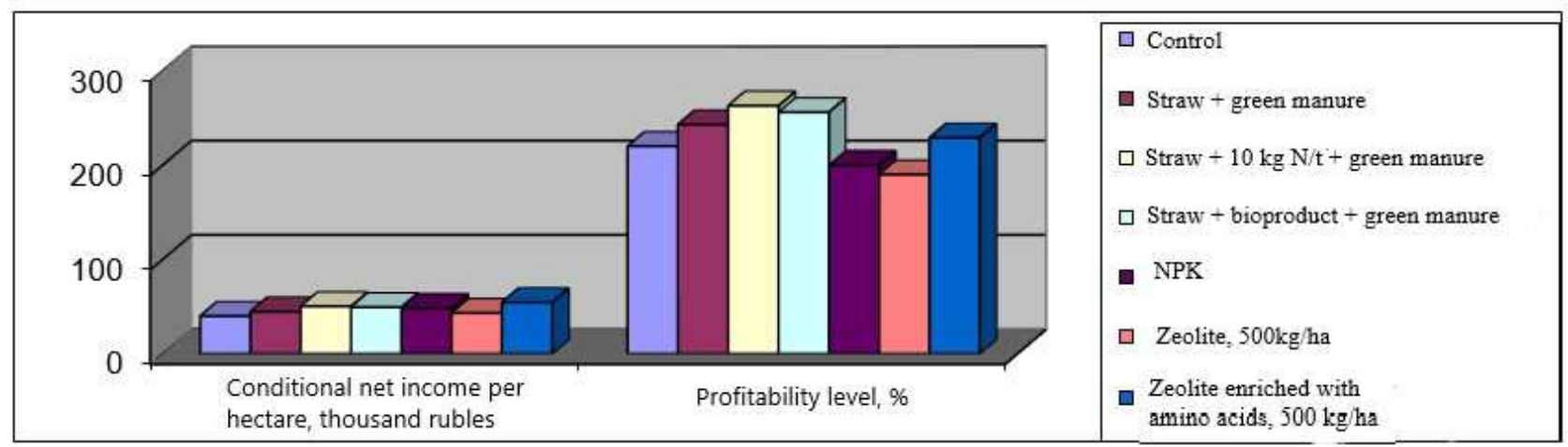

Fig. 2. Economic efficiency of winter wheat cultivation technologies

\section{Conclusion}

1. The combined use of straw and nitrogen in a dose of $10 \mathrm{~kg} / \mathrm{t}$ and green manure, as well as straw, biological products and green manure improved the nutritional regime of typical chernozem: the content of mineral nitrogen in the arable layer increased by $1.0-1.4 \mathrm{mg} / \mathrm{kg}$, the content of available phosphorus compounds increased by $5-7 \mathrm{mg} / \mathrm{kg}$ and the content of potassium increased by $14-12 \mathrm{mg} / \mathrm{kg}$. When zeolite and zeolite fertilizers were introduced into the soil, the nitrogen regime of the soil exceeded the option with mineral fertilizers.

2. When applying organic fertilizers in the form of straw, Biocomposite-correct, and a vetch-oat mixture as a green manure, the yield of winter wheat grain was slightly inferior to the option with a mineral fertilizer; it amounted to $6.82 \mathrm{t} / \mathrm{ha}$. The yield of winter wheat when zeolite enriched with amino acids was introduced into the soil was $7.84 \mathrm{t} / \mathrm{ha}$, exceeding the option with mineral fertilization by $0.59 \mathrm{t} / \mathrm{ha}$.

3. The use of organic (straw, biopreparation, green manure) and organo-mineral zeolite fertilizers enriched with amino acids is cost-effective and allows you to obtain higher quality and environmentally friendly products in comparison with the cultivation of winter wheat using mineral fertilizers.

\section{References}

1. A.Kh. Sheudzhen, T.I. Bondareva, S.V. Kizinyuk, Agrochemical basis for the use of fertilizers (Polygraph-Yug, Maykop, 2013)

2. A.Kh. Kulikova, E.A. Yashin, E.V. Danilova, The effectiveness of the use of diatomite and mineral fertilizers in the technology of cultivation of winter wheat, Agrochem. Bull., 5, 18-19 (2007)

3. M. Greger, T. Landberg, S. Nazaralian, Plant uptake of silicon nanoparticles, 7th Int. Conf. Silicon Agricult. Proced. Abstracts (India, 2017)

4. P.J. Van Soest, Rice straw, the role of silica and treatments to improve quality, Animal Feed Sci. Technol., 130, 137-171 (2006)

5. N. Yamaji, N. Mitani-Veno, G. Sakurai, J.F. Ma, A cooperative system of silicon transport in plants, $7 \mathrm{th}$ 
Int. Conf. Silicon Agricult. Proced. Abstracts (India, 2017)

6. N.E. Samsonova, Silicon in Plants and Animal Organisms, Agrochem., 1, 86-96 (2019)

7. A.E. Yashin, The productivity of winter wheat with the use of straw, green manure and a biological preparation on the typical chernozem of the foreststeppe of the Middle Volga region, Cand. dissertation thesis (Ulyanovsk, 2019)

8. G.V. Kolsanov, Buckwheat straw in barley fertilization on a typical chernozem of the Volga forest-steppe, Agrochem., 5, 59-65 (2005)

9. K.N. Dovban, Green Fertilizer (Agropromizdat, 1990)
10. S.M. Nadezhkin, N.V. Korchagina, Changes in soil fertility when using green manure, Agrochemical research (Belgorod, 1997), pp. 257-260

11. V.V. Matychenkov, The role of mobile silicon compounds in plants in the soil-plant system, Doct. dissertation thesis (Pushchino, 2008)

12. E.L. Datnoff, S.B. Tubona, Why is silicon still not used routinely for monaging plant health and enhacing plant growth under greenhouse and field conditions?, 7th Int. Conf. Silicon Agricult. Proced. Abstracts (India, 2017)

13. W.L. Lindsay, Chemical Equilibris in Soil (John Willey Sous, New York, 1979) 